R. Hist6ria, São Paulo, n. 127-128, p. 187-234, ago-dez/92 a jan-jul/93.

\title{
HISTÓRIA: NOVOS PERIÓDICOS BRASILEIROS
}

Pós-História (Revista de Pós-Graduação em História, UNESP). Assis, UNESP, 1, 1993.

Anos 90 (Revista do Curso de Pós-Graduação em História da UFRGS). Porto Alegre, UFRGS, 1, maio de 1993.

Textos de História (Revista de Pós-Graduação em História da UnB). Brasnlia, UnB, 1, 1993.

O nascimento de periódicos especializados em História pode contribuir para maiores contatos entre diferentes centros de pesquisa na área.

Para tanto, é importante que cada um garanta, além de continuidade e regularidade na publicação, derivadas đe efetivo compromisso da instituição que os criou com sua sobrevivência, a consolidaçāo de projeto original, articulado à produção intelectual da entidade editora e dialogando com centros de pesquisa nacionais e internacionais. Convém, ainda, evitar a repetição de soluçōes já existentes (o fácil "abrir janelas arrombadas"), a dispersāo de recursos (preservar tal generalidade temática e metodológica que não se percebe como cada publicação se diferencia de suas similares, exceto pelo ângulo gráfico) e a tendência a mesclar os estilos de "diário oficial" e "house organ" - impressão compulsória dos textos produzidos pela unidade que a mantém, destinando-os, prioritária e redundantemente, a consumo interno.

Os recentes lançamentos da UNESP, UFRGS e UnB exemplificam algumas dessas possibilidades. Um traço que as liga é sua vinculação a Programas de Pós-Graduação em História. Noutros aspectos, já se particula-

- Professot no Departamento de História/FFLCH-USP. 
R. Histórla, S\&o Paulo, a. 127-128, p. 187-234, ago-de2/92 a jao-jul/93.

rizam, o que se constitui em rica contribuição para o debate entre Profissionais de História.

O projeto editorial de $P$ Ps-História foi elaborado e dirigido por Alunos do Programa de Pós-Graduaçāo da UNESP/Assis. Ele evidencia compromissos com pesquisas produzidas por Docentes e Discentes daquela instituição, bem como de outras universidades brasileiras (UNICAMP, USP) e estrangeiras - caso do comentário de Darnton sobre Darmon e usos recentes de Foucault por historiadores.

Sua estruturação geral atesta a preocupação de preservar identidade institucional e padrāo intelectual, como se observa na constituição de Conselho Consultivo (docentes do programa) e na proposta de sua Comissão Editorial ser rotativa a cada edição, agrupando representantes do corpo discente, que garantiu o surgimento e implantação da revista, e do professorado.

Em termos temáticos e metodológicos, esse número inaugural soube explorar questōes relevantes da pesquisa histórica contemporanea, como Memória, Cultura Popular, História Oral e Fontes Alternativas, dentre outras, demonstrando plena articulaçāo com diferentes tendéncias nessa área de saber e com as linhas de pesquisa do Programa de Pós-Graduação que o editou - Mentalidades, Movimentos Sociais, Instituiçóes e História Regional.

O próprio título da publicação insinua tensões entre sua condição de órgảo de um Programa de Pós-Graduação em História e o anunciado "fim da História" de alguns debates recentes, sem, todavia, endossar tal tese. Sua đivisão em seçốes (Artigos, Ensino, Documentos, Resumos de Teses, Resenhas) remete para modelos clássicos desse tipo de publicação, facilitando a leitura e a remessa de originais para a seleção.

Por todas essas características, Pos-Historia abriga múltiplas potencialidades, devendo repercutir junto a centros similares de estudos históricos, abrindo diálogos para o enriquecimento recíproco dessas unidades de pesquisa.

Anos 90 contém no próprio título um estimulante vínculo entre saberes históricos e tempo presente. Essa feliz escolha apenas poderá ser comprometida pela desejável continuidade da publicação: ela se chamará Anos Zero a partir de 2001?

Seu Consetho Editorial agrupa Docentes da UFRGS. O corpo de artigos, todavia, apelou somente para Pesquisadores de outras instituiçóes IUPERJ, USP, UNICAMP, Universidad de Buenos Aires e Universidad Nacional de Rosário. É claro que o diálogo da UFRGS com essas entidades é necessário mas sua plena efetivação ocorrerá apenas quando os Docentes e Discentes do Programa de Pós-Graduação que edita a revista tambem se 
R. Hist6ria, S5o Paulo, a. 127-128, p. 187-234, ago-dez/92 a jan-jul/93.

fizerem presentes em suas páginas como Autores de artigos e outros itens. Isso será muito fácil, como se observa no elenco dos Cadernos de Estudos, publicados pela mesma instituição, e na frequente participação de seus Professores e Alunos como Autores em periódicos nacionais e estrangeiros.

A publicação se destaca, desde já, por bom padrão gráfico e esforço para agrupar temas e problemáticas recentes de pesquisa histórica, como Imaginário e Memória, dentre outros, que se relacionam com as linhas de pesquisa da Pós-Graduação em História da UFRGS - Teoria e Metodologia, Região Platina e Rio Grande do Sul.

Textos de História é revista da Pós-Graduação em História da UnB. Desejamos aos três periódicos boas vindas e longa vida. 